\title{
E3 Ubiquitin-Protein Ligase RFWD3
}

National Cancer Institute

\section{Source}

National Cancer Institute. E3 Ubiquitin-Protein Ligase RFWD3. NCI Thesaurus. Code C138093.

E3 ubiquitin-protein ligase RFWD3 (774 aa, $~ 85 \mathrm{kDa}$ ) is encoded by the human RFWD3 gene. This protein is involved in the ubiquitination of proteins that regulate the DNA damage checkpoint during the cell cycle. 